\title{
MINERALOGICAL, PETROLOGICAL AND GEOCHEMICAL FEATURES OF THE UNIQUE LAPIS LACEDAEMONIUS (KROKEATIS LITHOS) FROM LACONIA, GREECE: APPROACH ON PETROGENETIC PROCESSES WITHIN THE TRIASSIC VOLCANIC CONTEXT
}

\author{
Koutsovitis P. ${ }^{*}$, Kanellopoulos C. ${ }^{1}$, Passa S. ${ }^{1}$, Foni K. ${ }^{2}$, Tsapara E. ${ }^{1}$, \\ Oikonomou G. ${ }^{1}$, Xirokostas N. ${ }^{1}$, Vallianatou K. ${ }^{1}$ and Mouxiou E. ${ }^{1}$ \\ ${ }^{1}$ Institute of Geology and Mineral Exploration, $1^{\text {st }}$ Spirou Louis St., Olympic Village, Acharnae, \\ GR, 13677 \\ ${ }^{2}$ Faculty of Geology and Geoenvironment, National \& Kapodistrian University of Athens. \\ UniversityCampus-Zografou, Athens, GR, 15784 petroskoutsovitis@yahoo.com, \\ ckanellopoulos@gmail.com,passa@upatras.gr,kallirroe.f@gmail.com,efi.tsapara@gmail.com, \\ georgeoik7@gmail.com,nikosxirokostas@yahoo.com,kalliav@yahoo.com, \\ elenimouxiou@yahoo.com
}

\begin{abstract}
The Lapis Lacedaemonius (krokeatis lithos) is a well-known meta-volcanic rock of great historical importance. Petrographic observations, mineral chemistry data, as well as geochemical analysis of selected samples, reveal that these rocks are porphyritic metabasaltic rocks which have been significantly affected by saussuritization and also by restricted silicification processes. They represent subduction related calc-alkaline volcanic rocks which also appear in the adjacent Hellenic Triassic volcanic outcrops, and appear to be associated with the rift/drift phase within the Pindos oceanic realm. The unique features of the Lapis Lacedaemonius, when compared to geochemically similar volcanic rock outcrops, are mainly attributed to their distinct porphyritic textures, predominantly with microlithically textured groundmass along with the coarse grained plagioclase, and to saussuritization processes. The Lapis Lacedaemonius seems to have been formed in a sub-volcanic system closely associated with epidosites, suggesting that metasomatism occurred within hydrothermal upflow zones.

Keywords: Lapis Lacedaemonius, Krokeatis lithos, Saussuritization, Subduction, Triassic volcanism.

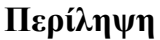

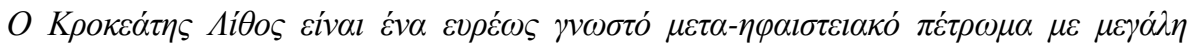

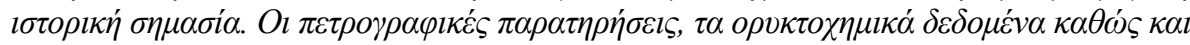

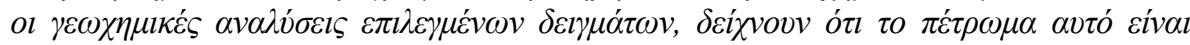

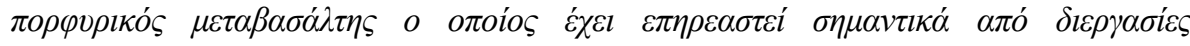

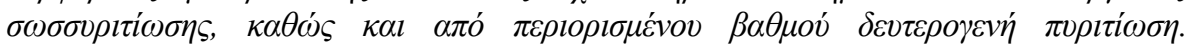

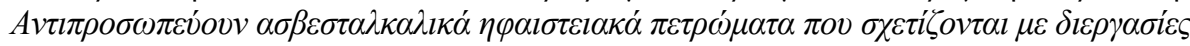

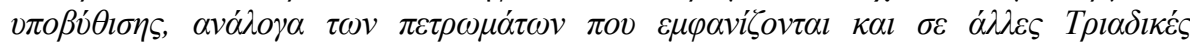

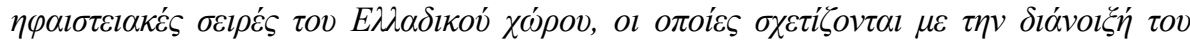




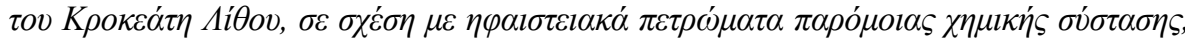

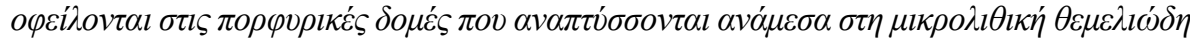

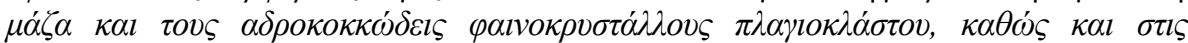

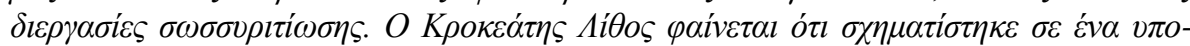

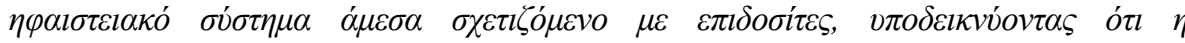

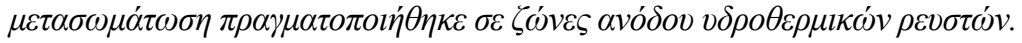

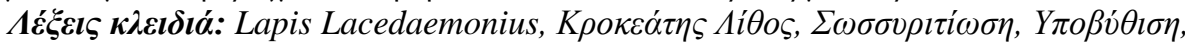

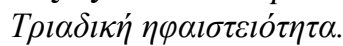

\section{Introduction}

Lapis Lacedaemonius (Krokeatis lithos) is a well-known volcanic rock since the ancient times. Although it was very difficult material to processes, in antiquity it was used for the manufacture of vases, seals and for the decoration of buildings. It is referred by Pausanias who noted the outcrops locality, as well as its importance in ancient times, since it had been used as raw material since the Minoan period. Later on, the Romans largely extracted this stone for decorative elements. Few of the noteworthy monuments where the Lapis Lacedaemonius has been found are: the ancient acropolis of Mycenae, the palace of King Minos (Knossos, Crete), the baths next to the temple of Poseidon (Corinth), Basilica of Saint Peter, (Rome), Agia Sofia church (Constantinople), Westminster Abbey (London), the ruins of ancient Pompeii and Saint Marc church (Venice). Consequently, it is known with several names; Krokeatis lithos, Porfido verde antico, Marmor Lacedaemonium, Spartan basalt, green stone from Taygetus, Green Porphyry, Viride or Porfido serpentino verde, Krokeischer Stein (e.g. Zezza and Lazzarini, 2002; Wilson, 2013; KokkorouAlevra, 2014). The only known occurrence of Lapis Lacedaemonius is near the village of Krokees (old name Levetsova) in Laconia, Northern Southern Peloponnese.

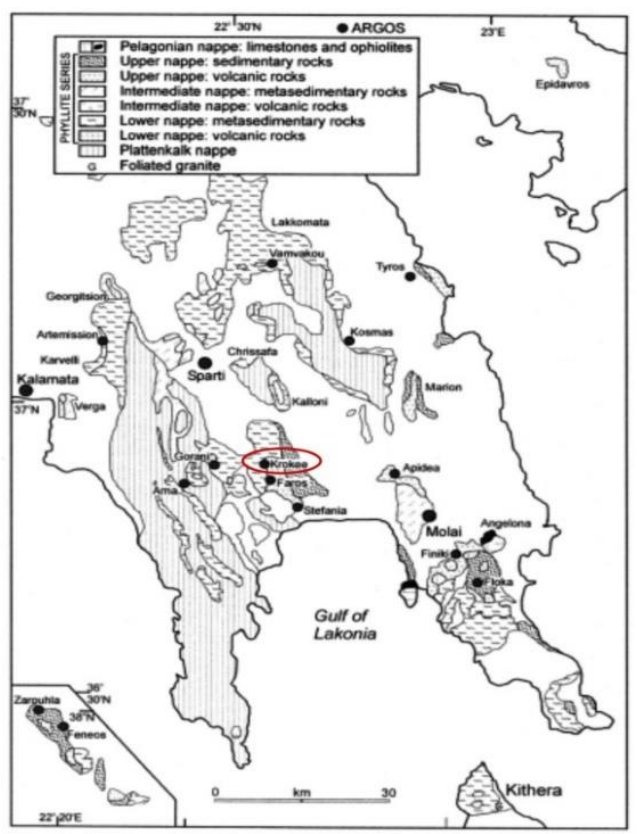

Figure 1 - Simplified geological map of Triassic volcanic rocks in the southern Peloponnese (Pe-Piper and Piper, 2002).

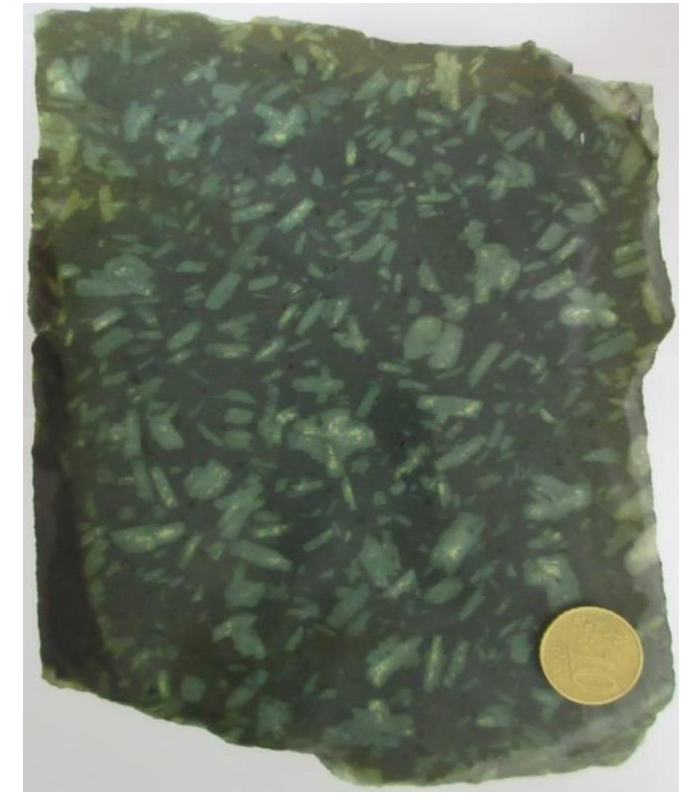

Figure 2 - Hand specimen of Lapis Lacedaemonius presenting characteristic porphyritic texture. 
From a geologic aspect, this metavolcanic rock occurrence is part of the Triassic volcanism, which is widespread throughout the mainland of Greece, as part of the Sub-Pelagonian Zone. These volcanic occurrences, which mostly include pillow lavas and massive flows, are associated with the rift/drift phase within the Pindos oceanic realm. In the past, several studies were conducted focusing mostly to the entire Triassic volcanism of the area (Panagos, 1979; Thiebault, 1982; Pe-Piper et al., 1982; Gerolymatos, 1994; Pe-Piper and Piper, 2002). The current study aims to characterize mineralogically and geochemically the Lapis Lacedaemonius (Krokeatis lithos), in an attempt to interpret from a geological scope the reasons for its uniqueness and its absence in other Triassic volcanic localities. In order to accomplish the aforementioned, scientists with different scientific specialization have collaborated to achieve a multidiscipline approach.

\section{Geological Setting}

Lapis Lacedaemonius is an altered porphyritic basaltic rock which occurs near the village of Krokees (Fig. 1) and is considered as being part of the rift/drift related Triassic volcanism of the Hellinides, which in geotectonic terms may be considered as part of the Sub-Pelagonian Zone (Sharp and Robertson, 2006). The Triassic nappes in the region are termed as the Phyllite-Quarzite Series (Thiebault, 1982; Pe-Piper and Piper, 1991, 2002). These include Paleozoic to Early Triassic pelagic brecciated limestones/marbles and metasedimentary rocks (phyllites, metaconglomerates, metasandstones). The overlaying Tyros beds, mostly exposed in Lakonia, comprise a volcanic and sedimentary sequence, which includes altered basaltic/andesitic pillows, thick pyroclastic series, as well as minor basaltic, dacitic or rhyolitic massive flows and hypabyssal intrusions, while the sedimentary rocks include minor dolomite, sandstone and shale fragments (Gerolymatos, 1994; PePiper and Piper, 2002 and references therein). This nappe is locally conformably overlain by Triassic limestone, passing up into the Tripolitsa limestone (Thiebault, 1982). The volcanic rocks in Lakonia and subsequently in Krokees are basaltic rocks that have undergone low-grade metamorphism (Fig. 2) and are often accompanied by epidosites, which formed by pervasive alteration of the basalts. These volcanic rocks lack significant penetrative deformation features (Thiebault, 1982; Gerolymatos, 1994).

\section{Materials and Methods}

Thin polished sections were made from three selected samples and examined by transmitted light mic roscopy and scanning electron microscopy-energy dispersive spectroscopy (SEM-EDS), using a JEO L JSM 5600 scanning electron microscope, equipped with an automated energy dispersive analysis s ystem ISIS 300 OXFORD, with the following operating conditions: $20 \mathrm{kV}$ accelerating voltage, $0.5 \mathrm{n}$ A beam current, $20 \mathrm{~s}$ time of measurement and $5 \mu \mathrm{m}$ beam diameter. The spectra were processed usin $\mathrm{g}$ the ZAF program (3 iterations). The mineralogical composition of the samples was also investigated by powder X-ray diffraction (XRD). The XRD study was carried out using a Philips XPert Panalytical $\mathrm{X}$-ray diffractometer, operating with $\mathrm{Cu}$ radiation at $40 \mathrm{kV}, 30 \mathrm{~mA}, 0.020$ step size and $1.0 \mathrm{sec}$ step time. The XRD patterns were evaluated using the DIFFRACplus EVA software v.11 (Bruker-AXS, USA) based on the ICDD Powder Diffraction File (2006). Part of these three samples were pulverized to $<200$ mesh in an agate mill and were digested with a mixture of $\mathrm{HCl}-\mathrm{HNO}_{3}-\mathrm{HF}$ acids and was analyzed for a series of trace elements by Inductively Coupled Plasma-Atomic Emission Spectroscopy (ICP-MS) and a series of major elements by X-ray fluorescence (XRF). All samples were analyzed at the Laboratories of the Institute of Geology and Mineral Exploration (I.G.M.E.).

\section{Results and Discussion}

\subsection{Petrography and mineral chemistry}

The Lapis Lacedaemonius samples consist of altered prismatically lath-shaped subhedral plagioclase phenocrysts, with their size reaching up to $2 \mathrm{~cm}$, as well as of a groundmass exhibiting microphitic or symplectitic textures (Fig. 3). Based upon petrographic observations (Fig. 3), XRD peak patterns (Fig. 4) and mineral chemistry (Table 2), it is determined that the groundmass consists 
mainly of albite, clinopyroxene, epidote, magnetite, quartz, titanite and rare devitrified glass composed of chlorite. In particular, clinopyroxene grains are found only within the groundmass and are classified as augite, exhibiting moderate $\mathrm{TiO}_{2}\left(0.35-0.72\right.$ wt. \%), $\mathrm{Al}_{2} \mathrm{O}_{3}$ (1.75-2.28 wt.\%) and low $\mathrm{Na}_{2} \mathrm{O}$ and $\mathrm{Cr}_{2} \mathrm{O}_{3}$ contents (representative analyses in Table 2). The groundmass along with the coarse grained plagioclase crystals forms characteristic porphyritic and also glomeroporphyritic textures. The medium to coarse grained plagioclase crystals have undergone extensive saussuritization processes, including albite/oligoclase relicts, epidote, pumpellyite, sericite, quartz and magnetite. Epidote and prehnite, pumpellyite are more frequent within the cores of the former basic plagioclase feldspars but they also appear within the groundmass. The occurrence of epidote, pumpellyite, prehnite, pumpellyite and sericite strongly suggests that these rocks underwent low-grade metamorphic/metasomatic processes. Despite the prevailing metasomatism, metamorphic degrees are restricted, which is confirmed by the absence of secondary amphibole. Secondary amygdales (1$2 \mathrm{~mm}$ ) are filled with mixtures of epidote, chlorite, pumpellyite and rarely calcite (Figure 3B, C).

Table 1 - Representative microanalyses of Lapis Lacedaemonius samples.

\begin{tabular}{|c|c|c|c|c|c|c|c|c|c|c|}
\hline $\begin{array}{l}\begin{array}{l}\text { Mineral } \\
\text { Sample }\end{array} \\
\text { Comments } \\
\end{array}$ & $\begin{array}{l}\text { Cpx } \\
\text { KR1 } \\
\text { within } \\
\text { matrix } \\
\end{array}$ & $\begin{array}{c}\text { Cpx } \\
\text { KR3 } \\
\text { within } \\
\text { matrix } \\
\end{array}$ & $\begin{array}{c}\mathbf{A b} \\
\mathrm{KR} 3 \\
\text { within } \\
\text { matrix }\end{array}$ & $\begin{array}{c}\text { Olig } \\
\text { KR1 } \\
\text { within } \\
P L \\
\end{array}$ & $\begin{array}{c}\text { Ser } \\
\text { KR3 } \\
\text { within } \\
P L \\
\end{array}$ & $\begin{array}{c}\text { Ep } \\
\text { KR3 } \\
\text { Sec. } \\
\text { amygd. }\end{array}$ & $\begin{array}{c}\text { Pmp } \\
\text { KR1 } \\
\text { within } \\
P L \\
\end{array}$ & $\begin{array}{c}\text { Prh } \\
\text { KR2 } \\
\text { within } \\
P L \\
\end{array}$ & $\begin{array}{c}\text { Chl } \\
\text { KR1 } \\
\text { Sec. } \\
\text { amygd. }\end{array}$ & $\begin{array}{c}\text { Ttn } \\
\text { KR2 } \\
\text { within } \\
\text { matrix } \\
\end{array}$ \\
\hline $\mathrm{SiO}_{2}$ & 51.87 & 51.62 & 67.47 & 62.16 & 45.87 & 37.84 & 38.84 & 44.82 & 28.38 & 29.88 \\
\hline $\mathrm{TiO}_{2}$ & 0.58 & 0.46 & - & - & 0.17 & 0.3 & - & - & - & 33.29 \\
\hline $\mathbf{A l}_{2} \mathbf{O}_{3}$ & 1.72 & 2.13 & 20.56 & 23.43 & 35.31 & 22.34 & 26.97 & 25.29 & 19.54 & 2.25 \\
\hline $\mathrm{FeO}_{\mathrm{t}}$ & 11.74 & 11.76 & 0.21 & 0.37 & 1.98 & 11.22 & 3.93 & 3.26 & 22.74 & 4 \\
\hline MnO & 0.24 & 0.31 & - & 0.08 & - & - & - & 0.29 & 0.12 & - \\
\hline MgO & 14.81 & 15.34 & - & 0.15 & 1.56 & 1.81 & 1.77 & - & 15.91 & 0.19 \\
\hline $\mathrm{CaO}$ & 18.91 & 18.67 & 2.17 & 4.88 & 0.76 & 22.4 & 21.33 & 20.78 & 0.34 & 26.79 \\
\hline $\mathrm{Na}_{2} \mathrm{O}$ & 0.35 & 0.23 & 9.84 & 9.26 & 0.79 & 0.38 & 0.03 & 0.89 & - & 0.63 \\
\hline $\mathbf{K}_{2} \mathbf{O}$ & 0.04 & 0.1 & 0.29 & 0.1 & 10.27 & 0.08 & 0.32 & 0.18 & - & 0.16 \\
\hline $\mathrm{Cr}_{2} \mathrm{O}_{3}$ & 0.25 & 0.2 & - & - & - & 0.09 & 0.27 & - & 0.1 & 0.18 \\
\hline $\mathrm{NiO}$ & 0.24 & 0.08 & - & - & - & 0.04 & 0.02 & - & 0.04 & - \\
\hline Total & 100.75 & 100.9 & 100.54 & 100.43 & 96.71 & 96.5 & 93.48 & 95.51 & 87.18 & 97.37 \\
\hline \multicolumn{11}{|l|}{ Atoms } \\
\hline Si & 1.924 & 1.908 & 2.968 & 2.734 & 3.030 & 2.982 & 3.138 & 3.076 & 2.935 & 1.016 \\
\hline $\mathbf{T i}$ & 0.016 & 0.013 & 0.000 & 0.000 & 0.008 & 0.018 & 0.000 & 0.000 & 0.000 & 0.851 \\
\hline Al & 0.075 & 0.093 & 1.066 & 1.214 & 2.749 & 2.075 & 2.568 & 2.046 & 2.395 & 0.090 \\
\hline $\mathbf{F e}$ & 0.364 & 0.363 & 0.008 & 0.014 & 0.109 & 0.739 & 0.266 & 0.168 & 1.966 & 0.114 \\
\hline Mn & 0.008 & 0.010 & 0.000 & 0.003 & 0.000 & 0.000 & 0.000 & 0.017 & 0.011 & 0.000 \\
\hline Mg & 0.819 & 0.845 & 0.000 & 0.010 & 0.154 & 0.213 & 0.213 & 0.000 & 2.452 & 0.010 \\
\hline $\mathrm{Ca}$ & 0.752 & 0.739 & 0.102 & 0.230 & 0.054 & 1.892 & 1.847 & 1.528 & 0.038 & 0.976 \\
\hline $\mathrm{Na}$ & 0.025 & 0.016 & 0.839 & 0.790 & 0.101 & 0.058 & 0.005 & 0.118 & 0.000 & 0.042 \\
\hline $\mathbf{K}$ & 0.002 & 0.005 & 0.016 & 0.006 & 0.865 & 0.008 & 0.033 & 0.016 & 0.000 & 0.007 \\
\hline $\mathrm{Cr}$ & 0.007 & 0.006 & 0.000 & 0.000 & 0.000 & 0.000 & 0.000 & 0.000 & 0.008 & 0.005 \\
\hline $\mathbf{N i}$ & 0.007 & 0.002 & 0.000 & 0.000 & 0.000 & 0.000 & 0.000 & 0.000 & 0.003 & 0.000 \\
\hline tot. cat. & 4.00 & 4.00 & 5.00 & 5.00 & 7.07 & 7.98 & 8.07 & 6.97 & 9.81 & 3.11 \\
\hline tot. oxy. & 6 & 6 & 8 & 8 & 11 & 12 & 12.5 & 11 & 14 & 5 \\
\hline
\end{tabular}

Note: Pl: plagioclase; Ab: albite; An25: oligoclase; Cpx; clinopyroxene, Ep: epidote; Ser: sericite; Chl: chlorite; Mag: magnetite; Pmp: pumpellyite; Prh: prehnite; Qrz: quartz; Aug: augite. 

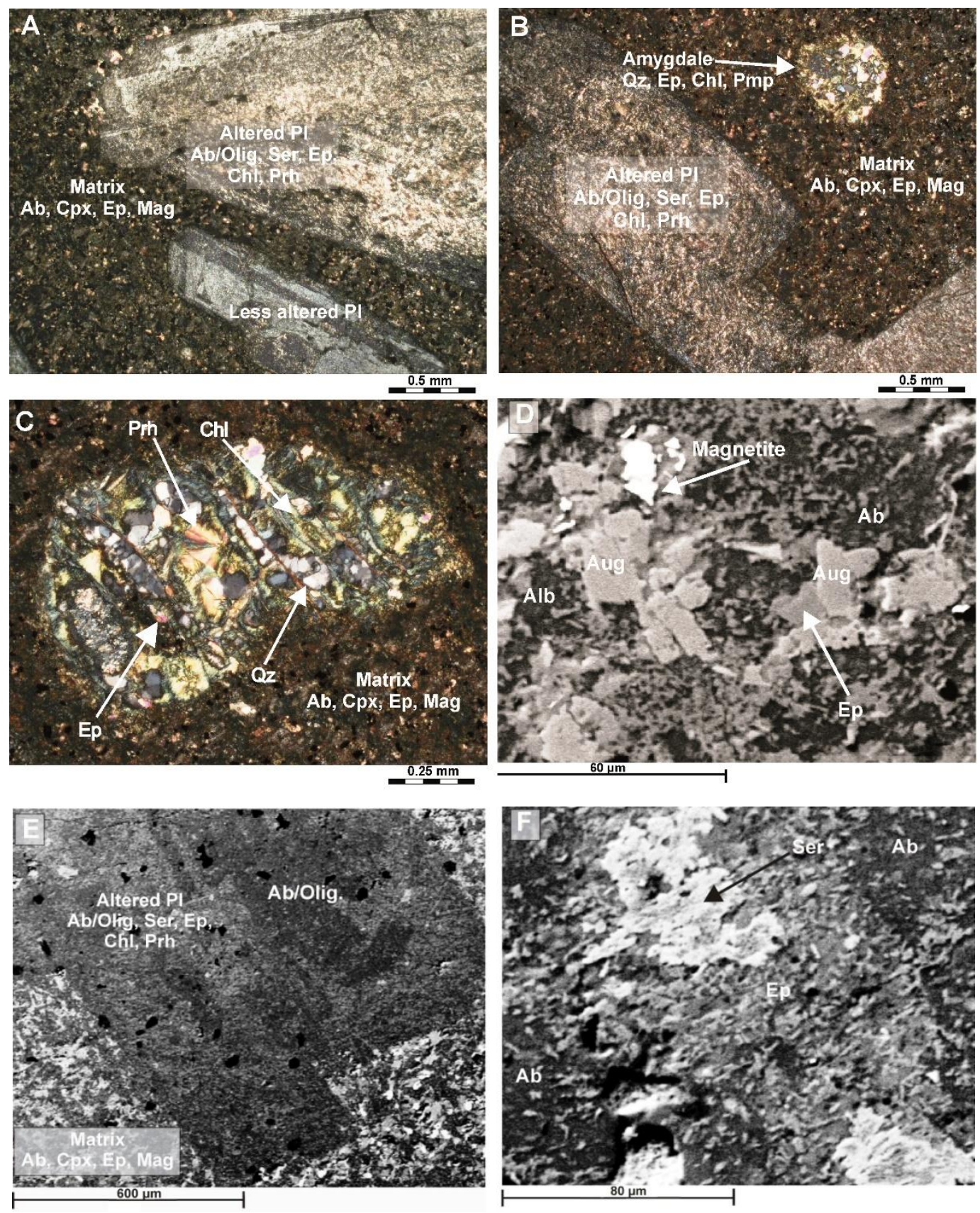

Figure 3 - Photomicrographs and back-scattered electron (BSE) images of Lapis

Lacedaemonius samples; (A) Altered plagioclase phenocrysts within the micritic groundmass; (B) Altered plagioclase phenocrysts and amygdale within the groundmass; (C) Amygdale within the groundmass. (D) Micritic groundmass area; (E) Altered plagioclase phenocrysts with relict albite; (F) BSE image within the center of the plagioclase phenocryst. 


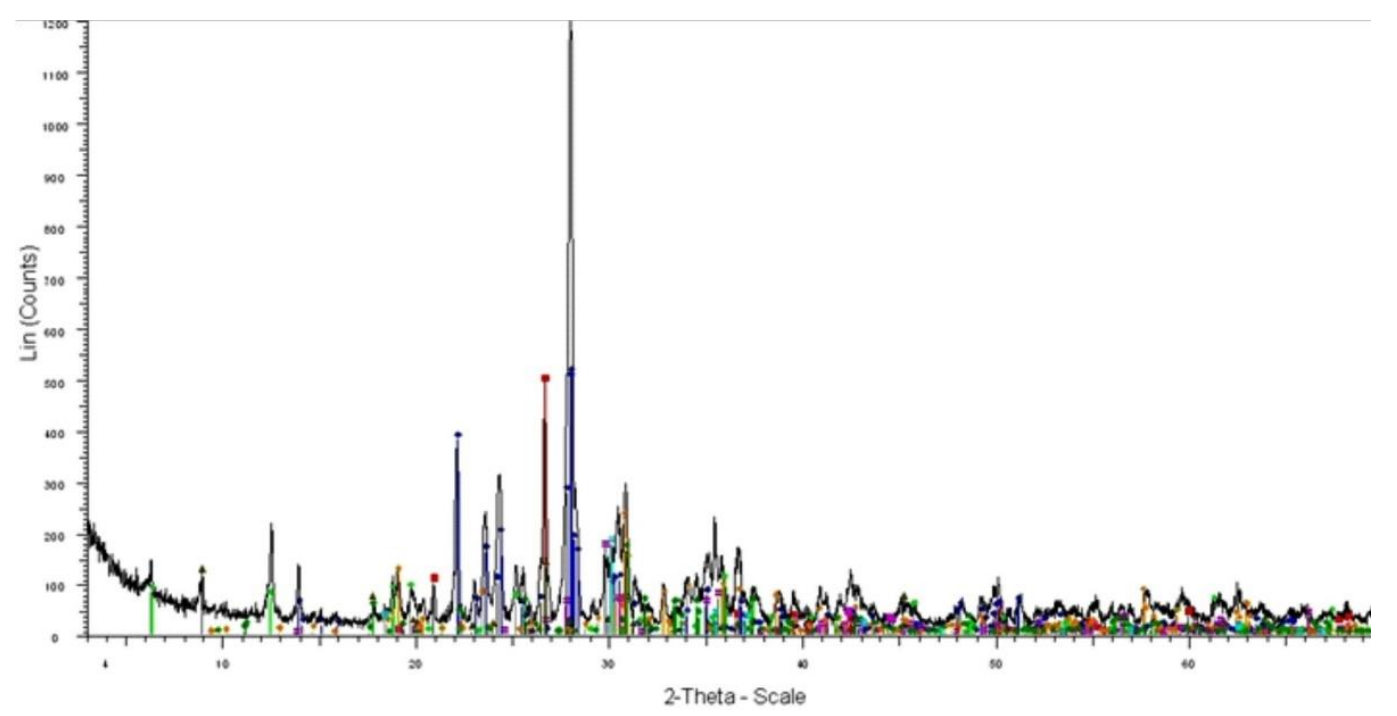

Figure 4. Evaluated XRD pattern of representative Lapis Lacedaemonius.

\subsection{Whole-rock geochemistry}

Rock classification of the studied metavolcanic Lapis Lacedaemonius (Krokeatis lithos) samples was based upon the binary diagram of Winchester and Floyd (1977), modified by Pearce (1996), which incorporates relatively immobile elements, since Lapis Lacedaemonius have been affected by low-grade metamorphic and metasomatic processes. Based upon this diagram (Fig 5A) and on their petrographic features, samples are classified as porphyritic basalts. These rocks are regarded by many authors (e.g. Pe-Piper et al., 1982; Zezza and Lazzarini, 2002) as porphyritic andesites. However, this classification has been based upon their silica and alkali contents that were affected by metamorphic and metasomatic processes. On a volatile free basis, the rocks of this study have relatively high $\mathrm{Al}_{2} \mathrm{O}_{3}$ contents (19.39-19.93 wt. \%), as well as rather high $\mathrm{TiO}_{2}(0.84-0.89$ wt. \%) and low $\mathrm{MgO}$ (3.45-3.68 wt. \%) contents. Their $\mathrm{TiO}_{2}$ contents, as well as their relatively high $\mathrm{FeO}_{\mathrm{t}} / \mathrm{MgO}$ ratio values (2.35-2.37), can classify them as being Fe-Ti-rich, based upon the criteria of Melson et al. (1976) and Sinton et al. (1983) $\left(\mathrm{FeO}_{\mathrm{t}} / \mathrm{MgO}>1.75\right)$. Their relatively high $\mathrm{SiO}_{2}$ contents (53.33-54.24 wt. \%) and the occurrence of CIPW normative quartz, would classify these rocks as andesites, however, this is most likely the result of restricted silification, as confirmed from the petrographic observations. Their geochemical character can be regarded as transitional calc-alkaline, as shown on the Y vs. Zr binary plot (Fig. 5B).

Their MORB-normalized MREE and HREE patterns are subparallel (0.66-1.90 and 0.50$0.77 x$ MORB respectively; Fig. 5C), while their LREE are moderately enriched $\left[(\mathrm{La} / \mathrm{Yb})_{\mathrm{MORB}}=0.66\right.$ 1.90] (Fig. 5C). Eu anomalies vary from moderate to significant negative $\left(\mathrm{Eu}_{\mathrm{MORB}} / \mathrm{Eu}^{*}=0.66-0.84\right)$ which may be due to plagioclase fractionation, changes in $f \mathrm{O}_{2}$ conditions or crustal contamination of the source. The Middle to Upper Triassic calc-alkaline rocks from Lakmon (Pindos region), Gionna (Central Greece), Glykomilia (Koziakas region) (Magganas et al., 1997; Pomonis et al., 2004), South Othris (Koutsovitis et al., 2009), as well as from the eastern and south-western Peloponnese region (villages of Platano and Kokkino respectively) (Pe-Piper and Piper 1991, 2002) show similar and subparallel REE patterns, although the latter seem to be more comparable. On the other hand, the MORB-normalized incompatible trace element patterns (Fig. 5D) reveal that Th and $\mathrm{K}$ have higher normalized values than $\mathrm{Nb}$ and $\mathrm{Ta}$. $\mathrm{Zr}$ exhibits significant negative anomalies, while $\mathrm{Ti}$ shows moderate negative anomalies. Furthermore, the incompatible $\mathrm{Cs}$ and $\mathrm{Rb}$ are relative to other elements enriched. The calc-alkaline rocks from the referred adjacent localities present comparable enrichments and depletions, especially regarding the immobile elements. 


\subsection{Geotectonic and Mantle source interpretations}

In the MORB-normalized incompatible trace element patterns of the studied samples (Fig. 5D), the higher normalized values of $\mathrm{Th}$ and $\mathrm{K}$ relative to $\mathrm{Nb}$ and $\mathrm{Ta}$ most likely account for influence of subduction or crustal contamination processes (Pearce and Peate, 1995). Negative HFSE anomalies, such as those of $\mathrm{Ti}$ and $\mathrm{Zr}$, most often point to supra-subduction zone magmas (e.g. Saunders et al., 1991; McCulloch and Gamble, 1991). Similar assumptions can be inferred from the LILE Cs and Ba enrichments; however, secondary processes most likely affected their original magmatic values. The Ti-V-Sm ternary discrimination diagram (after Vermeesch, 2006; Fig. 5E), which incorporates immobile elements, clearly suggests that subduction related processes had a significant effect during rock-formation. Similar assumptions can be made from the binary diagram of $\mathrm{Th} / \mathrm{Yb} \mathrm{vs} . \mathrm{Nb} / \mathrm{Yb}$ (Fig. $5 \mathrm{~F}$ ), in which the studied samples plot above the MORB-OIB mantle array, but also from the strikingly low $\mathrm{Nb} / \mathrm{Th}$ ratio values, which are below the value of 4 , characterizing arc-related rocks (Sun and McDonough, 1989). From the same binary diagram, apart from the effect subduction, it seems that the samples were derived from an enriched mantle source.

The occurrence of alkaline and E-MORB lavas along with the calc-alkaline basalts and trachyandesites in Triassic localities in Greece, such as in Pindos (Pe-Piper and Piper, 2002; PePiper et al., 2004), Koziakas (Magganas et al., 1997; Pomonis et al., 2004) and South Othris (Koutsovitis et al., 2012), further supports this assumption. In addition, the $\mathrm{Zr} / \mathrm{Nb}$ ratios of the studied samples, which are almost independent from fractional crystallization and slab dehydration processes (e.g. Thirlwall et al., 1994; Pearce and Peate, 1995; Kamber and Collerson, 2000), may provide information concerning the nature of the mantle source. In particular, their $\mathrm{Zr} / \mathrm{Nb}$ ratios range between 10.9 and 15.2, which may be considered as very low, pointing to derivation from an enriched mantle source. This enriched source is most likely linked to the Early Triassic upwelling of plume-related asthenospheric OIB melts, shown by the high estimated mantle potential temperature $\left(\sim 1,370^{\circ} \mathrm{C}\right.$; Magganas and Koutsovitis, 2015$)$. Addition of slab related sedimentary components seems to have also taken place as implied by the relatively high $\mathrm{Th} / \mathrm{La}$ ratios $(0.25$ 0.41) (Plank, 2005). A plausible scenario to interpret the geotectonic setting for the formation of the Triassic studied rocks, as well as other comparable Triassic calc-alkaline lavas, is the occurrence of intra-oceanic local compressional tectonics, possibly related with a breakup of the early formed oceanic crust forming an infant subduction zone. This scenario has successfully interpreted the unusual Triassic ultramafic-mafic-felsic suite in Othris (Koutsovitis et al., 2012).

\subsection{Unique features of the Lapis Lacedaemonius}

The question which obviously arises is what are the reasons for the unique appearance of the Lapis Lacedaemonius (Krokeatis lithos) and why is it absent in other Triassic volcanic localities. The fact that this rock occurrence presents obvious geochemical similarities with other Triassic calc-alkaline volcanics reported throughout the Hellenic mainland, makes it even more difficult to interpret. Small differences in their chemistry and possibly variability in the influence of subduction or sediment components cannot explain this alone. What makes the Lapis Lacedaemonius unique compared to the other Triassic calc-alkaline volcanic rocks is the absence of K-feldspar, the presence of fewer clinopyroxene crystals and the higher modal composition of the groundmass, the larger in size plagioclase phenocrysts, the silicification processes and also the infrequency of calcite in comparison to sericite. The most reasonable explanation that can be given is related to the fact that the other Triassic calc-alkaline volcanic rocks appear mostly in the form of pillow lavas, whereas the Lapis Lacedaemonius seems to be part of a subvolcanic suite. Thus, large sized plagioclase crystals were most likely formed in relatively deeper levels before being brought to shallower levels by a differentiated melt. Their association with epidosites in veins and crosscutting intrusions indicates that metasomatism occurred within hydrothermal upflow zones, comparable to those occurring in sheeted dykes of SSZ ophiolites (Banerjee et al., 2000; Gillis, 2002). 

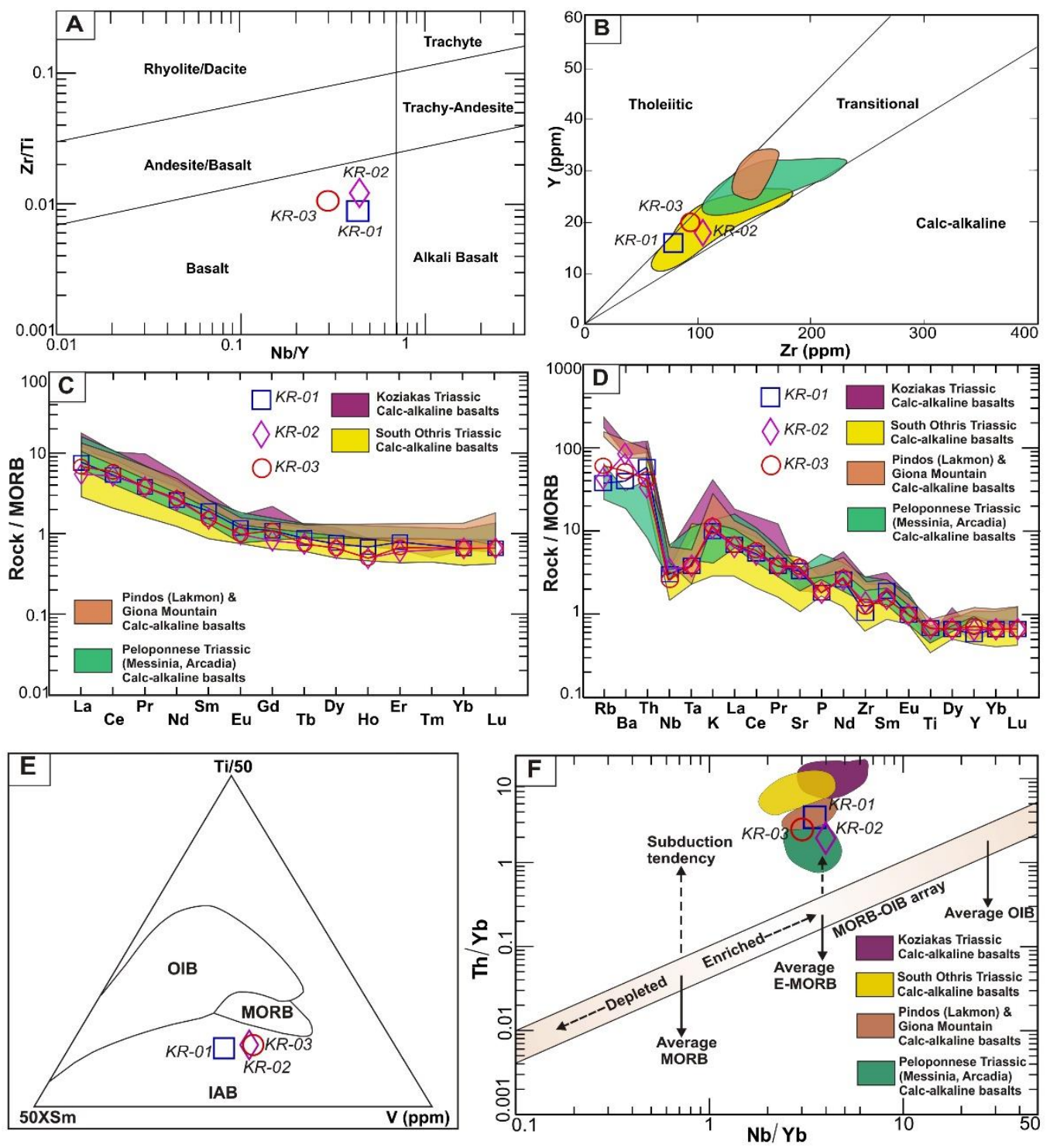

Figure 5. Lapis Lacedaemonius samples plotted on the: (A) $\mathrm{Zr} / \mathrm{Ti}$ vs. $\mathrm{Nb} / \mathrm{Y}$ diagram (Winchester and Floyd, 1977, modified by Pearce, 1996). (B) Y (ppm) against $\mathrm{Zr}$ (ppm) diagram (Barrett and Maclean, 1999). (C) MORB-normalized REE patterns. (D) MORBnormalized incompatible trace element patterns [normalization factors after Pearce and Parkinson (1993)]. (E) Ti-V-Sm diagram (after Vermeesch, 2006); (F) Th/Yb vs. Nb/Yb diagram (after Pearce, 2008). Triassic calc-alkaline volcanic rocks from Koziakas (Magganas et al., 1997; Pomonis et al. 2004), South Othris (Koutsovitis et al., 2009), Pindos (Lakmon) and Giona Mountain (Pe-Piper and Piper, 1991, 2002), Peloponnese (Messinia-Kokkino, Arcadia-Platanos villages) (Pe-Piper and Piper, 1991, 2002) are shown.

\section{Conclusions}

The Lapis Lacedaemonius (Krokeatis lithos) is a meta-volcanic rock of great historical importance. Its impressive and unique appearance was known even since the Minoan period and was used throughout ancient and medieval times as a raw material source. The studied samples reveal that 
Lapis Lacedaemonius is a subduction affected, transitional calc-alkaline basalt, formed during the Triassic volcanic period.

They exhibit many similarities compared with other Triassic calc-alkaline volcanic rocks from adjacent localities, showing that they were formed after interaction between E-MORB type volcanism and subduction related processes. Their differences which make the Lapis Lacedaemonius unique are mostly petrographic, accommodating higher modal plagioclase phenocrysts and micritic groundmass, both affected by saussuritization and restricted silicification processes, as well as the absence of clinopyroxene phenocrysts. It seems to have formed in a subvolcanic system closely associated with epidosites in the area, indicating that metasomatism occurred within hydrothermal upflow zones. In order to confirm these assumptions a more detailed study is anticipated in the short future so as to further investigate and unravel these processes.

\section{Acknowledgments}

We would like to express our thanks to an anonymous reviewer for the useful comments which helped to improve this paper. We express our appreciation to the Museum of Mineralogy and Petrology, at University of Athens and its Director Prof. Athanasios Katerinopoulos for allowing us to study one of the Lapis Lacedaemonius samples. Many thanks go to Pantelis Patsis, Michalis Sakalis and Dimitris Tarenidis of the Institute of Geological and Mineralogical Exploration (IGME) for their laboratory support.

\section{References}

Banerjee, N.R., Gillis, K.M. and Muehlenbachs, K., 2000. Discovery of epidosites in a modern oceanic setting, the Tonga forearc, Geology, 28(2), 151-154.

Barrett, TJ. and Maclean, WH., 1999. Volcanic sequences, lithogeochemistry, and hydrothermal alteration in some bimodal volcanic-associated massive sulfide systems. In: Barrie, C.T. and Hannington, M.D., eds., Volcanic-Associated Massive Sulfide Systems: Processes and Examples in Modern and Ancient Settings, Reviews in Economic Geology, 8, 101-131.

Gerolymatos, I., 1994. Metamorphose und Tektonik der Phyllit- Quartzit-Serie und der Tyros Formation auf dem Peloponnes und Kythira, Berliner Geowiss. Abh., 164-161.

Gillis, K.M., 2002. Root-zones of a fossil oceanic hydrothermal system exposed in the Troodos Ophiolite, The Journal of Geology, 110, 57-74.

Kamber, BS. and Collerson, KD., 2000. Zr/Nb Systematics of Ocean Island Basalts Reassessed-the Case for Binary Mixing, Journal of Petrology, 41(7), 1007-1021.

Kokkorou-Alevra, G., Poupaki, I., Efstathopoulos, A. and Hatzikonstantinou, A., 2014. Corpus of Ancient Greek Quarries. University of Athens, 350 pp. (In Greek).

Koutsovitis, P., Magganas, A. and Katerinopoulos, A., 2009. Calc-alkaline volcanic rocks in mélange formations from the South Othris region, Greece: petrogenetic and geo-tectonic implications, Geochemistry, Mineralogy, Petrology, 47, 79-95.

Koutsovitis, P., Magganas, A. and Ntaflos, T., 2012. Rift and intra-oceanic subduction signatures in the Western Tethys during the Triassic: the case of ultramafic lavas as part of an unusual ultramafic-mafic-felsic suite in Othris, Greece, Lithos, 144-145,177-193.

Magganas, A. and Koutsovitis, P., 2015. Composition, Melting and Evolution of the Upper Mantle beneath the Jurassic Pindos Ocean Inferred by Ophiolitic Ultramafic Rocks in East Othris, Greece, International Journal of Earth Sciences, 1-23.

Magganas, A., Kyriakopoulos, K. and Lekkas, E., 1997. Early Alpine Rift Volcanism in Continental Greece: the Case of Glykomilia Area (Koziakas Mountain), Chemie der Erde, 57, 243-255.

McCulloch, M.T. and Gamble, A.J., 1991. Geochemical and geodynamical constraints on subduction zone magmatism, Earth and Planetary Science Letters, 102, 358-374.

Melson, W.G., Vallier, T.L., Wright, T.L., Bryerly, G. and Nelson, J., 1976. Chemical diversity of abyssal volcanic glass erupted along the Pacific, Atlantic, and Indian Ocean seafloor 
spreading centers. In: Sutton, G., Manghari, M.H. and Moberly, R., eds., The geophysics of the Pacific Ocean Basin and its margins, Geophysical Monograph, 12, 351-367.

Panagos, A., Pe, G.G., Piper, D.J.W. and Kotopouli, C.N., 1979. Age and stratigraphic subdivision of the phyllite series, Krokee region, Peloponnese, Greece, Neu. Jb. Geol.-Paläont., Mh., 3, 181-190.

Pearce, J.A., 1996. A users guide to basalt discrimination diagrams. In: Wyman, D.A., ed., Trace Element Geochemistry of Volcanic Rocks: Applications for Massive Sulphide Exploration, Geological Association of Canada, Short Course Notes, 12, 79-113.

Pearce, J.A., 2008. Geochemical fingerprinting of oceanic basalts with applications to ophiolite classification and the search for Archean oceanic crust, Lithos, 100, 14-48.

Pearce, J.A. and Parkinson, I.J., 1993. Trace element models for mantle melting: application to volcanic arc petrogenesis. In: Prichard, H.M., Alabaster, T., Harris, N.B.W. and Neary, C.R., eds., Magmatic Processes and Plate Tectonics, Geological Society, London, Special Publications, 76, 373-403.

Pearce, JA. and Peate, D.W., 1995. Tectonic Implications of the Composition of Volcanic ARC Magmas, Annu. Rev. Earth Planet Sci., 23, 251-285.

Pe-Piper, G., 1982. Geochemistry, tectonic setting and metamorphism of the mid-Triassic volcanic rocks of Greece, Tectonophysics, 85, 253-272.

Pe-Piper, G., Panagos, A.G., Piper, D.J.W. and Kotopouli, C.N., 1982. The (?) mid Triassic volcanic rocks of Lakonia, Greece, Geological Magazine, 119, 77-85.

Pe-Piper, G. and Piper, D.J.W., 1991. Early Mesozoic oceanic subduction- related volcanic rocks, Pindos Basin, Greece, Tectonophysics, 192, 273-292.

Pe-Piper, G. and Piper, D.J.W., 2002. The Igneous Rocks of Greece, Borntraeger, Stuttgart, 1-645.

Pe-Piper, G., Tsikouras, B. and Hatzipanagiotou, K., 2004. Evolution of boninites and island-arc tholeiites in the Pindos Ophiolite, Greece, Geol Magazine, 141, 455-469.

Plank, T., 2005. Constraints from thorium/lanthanum on sediment recycling at subduction zones and the evolution of the continents, Journal of Petrology, 46, 921-944.

Pomonis, P., Tsikouras, B. and Hatzipanagiotou, K., 2004. Comparative geochemical study of the Triassic trachyandesites of Glykomilia and alkalibasalts from the Koziakas ophiolite mélange (W. Thessaly): implications for their origin, 10th G.S.G. Congress 2004, Bulletin of the Geological Society of Greece, 36, 587-596.

Saunders, A.D., Norry, M.J. and Tarney, J., 1991. Fluid influence on the trace element compositions of subduction zone magmas, Philosophical Transactions of the Royal Society of London, A335, 377-392.

Sharp, I.R. and Robertson, A.H.F., 2006. Tectonic-sedimentary evolution of the western margin of the Mesozoic Vardar Ocean: evidence from the Pelagonian and Almopias zones, northern Greece, Geol. Soc. London Spec. Publ., 260, 373-412.

Sinton, J.M., Wilson, D.S., Christie, D.M., Hey, R.N. and Delaney, J.R., 1983. Petrologic consequences of rift propagation on oceanic spreading ridges, Earth and Planetary Science Letters, 62, 193-207.

Sun, S.S. and McDonough, W.F., 1989. Chemical and isotopic systematics of oceanic basalts: implications for mantle composition and processes. In: Saunders, A.D. and Norry, M.J., eds., Magmatism in the Ocean Basins, Geol. Soc., London, Spec. Publ., 42, 313-345.

Thiebault, F., 1982. Evolution geodynamique des Hellenides externs en Peloponnese meridional (Greece), Soc. Geol. Nord, 6, 1-574.

Thirlwall, M.F., Upton, B.G.J. and Jenkins, C., 1994. Interaction between continental lithosphere and the Iceland plume-Sr- $\mathrm{Nd}-\mathrm{Pb}$ isotope geochemistry of Tertiary basalts, NE Greenland, Journal of Petrology, 35, 839-879.

Vermeesch, P., 2006. Tectonic discrimi-nation diagrams revisited, Geochem. Geophys. Geosyst., 7. Wilson, N., 2013. Encyclopedia of Ancient Greece, Hoboken, Taylor and Francis, 1-800.

Winchester, J.A. and Floyd, P.A., 1977. Geochemical discrimination of different magma series and their differentiation products using immobile elements, Chemical Geology, 20, 325-343.

Zezza, U. and Lazzarini, L., 2002. Krokeatis Lithos (Lapis Lacedaemonius): source, history of use, scientific characterization'. In: Lazzarini, L., ed., Interdisciplinary Studies on Ancient Stone, ASMOSIA VI, Padua. 